\title{
A new approach in bariatric operations: bridged mini gastric by-pass. Is rabbit model suitable for an experimental study?
}

\author{
Aziz Sümer ${ }^{1}$ (D), Sebahattin Çelik² (D), Talar Vartanoğlu Aktokmakyan³ (D), Çağhan Pekşen ${ }^{1}$ (D), Osman Anıl Savaş ${ }^{1}$ (D), Tutkun Talih ${ }^{4}$ (D), \\ Tunahan Sancak ${ }^{5}$ (D), Yağmur Kuşçu ${ }^{5}$ (D) \\ 1 Department of General Surgery, İstinye University Faculty of Medicine, Gaziosmanpaşa Medical Park Hospital, İstanbul, Turkey \\ 2 Department of General Surgery, Yüzüncü Yıl University Faculty of Medicine, Van, Turkey \\ ${ }^{3}$ Department of General Surgery, İstanbul Bağcilar Training and Research Hospital, Istanbul, Turkey \\ ${ }^{4}$ Department of General Surgery, Erciyes University Faculty of Medicine, Kayseri, Turkey \\ ${ }^{5}$ Yüzüncü Yıl University Faculty of Veterinary Medicine, Van, Turkey
}

\section{ABSTRACT}

Objective: Obesity is a global health epidemic with considerable co-morbidities. The increasing demand for bariatric surgery has led to the emergence of new techniques. We modified previously described Mini Gastric By-pass(MGB) technique via leaving a bridge at the most cranial $2 \mathrm{~cm}$ of the fundus of the human stomach to the follow-up and treatment of the remnant stomach and duodenum. We would like to entitle this new technique as Bridged MGB and aimed to apply on rabbits as an experimental study.

Material and Methods: The study was performed in the experimental animal laboratory of university after ethical approval was taken from the local ethics committee. Described new technique was applied to 2.1 and $3.2 \mathrm{~kg} 2$ New Zealand rabbits.

Results: As a result of the operations, one of the rabbits died on the day of the operation; the other rabbit was exitus postoperatively on the third day. In autopsies, although no problem was detected at the anastomoses, necrosis was detected in the large curvature of both rabbits.

Conclusion: Rabbit, one of the popular experimental animals, has been shown to be different from the human gastrointestinal system in both arterial and topographic aspects and it has been emphasized that it varies according to the species and even the diet and the climate. We believe that our study failed as a result of these differences and that animals more similar to humans should be used in gastrointestinal experimental studies.

Keywords: Experimental study, mini gastric bypass, rabbit

Cite this article as: Sümer A, Çelik S, Vartanoğlu Aktokmakyan T, Pekşen Ç, Savaş OA, Talih T, et al. A new approach in bariatric operations: bridged mini gastric by-pass. Is rabbit model suitable for an experimental study? Turk J Surg 2021; 37 (3): 294-298

\section{Corresponding Author}

Aziz Sümer

E-mail: drazizsumer@gmail.com

Received: 16.05 .2020

Accepted: 16.08.2020

Available Online Date: 28.09.202

( ) Copyright 2021 by Turkish Surgical Society Available online at www.turkjsurg.com

DOI: $10.47717 /$ turkjsurg.2021.4874

\section{INTRODUCTION}

Obesity and obesity-related disease (O-ORD) is a global health epidemic with considerable co-morbidities. Six hundred and fifty million adults and over 340 million children and adolescents are overweight or obese according to the World Health Organization (1). Surgical solutions have become increasingly popular following technical advances. Approximately 216.000 individuals underwent bariatric surgery in the United States according to the American Society for Metabolic and Bariatric Surgery since 2016 (2).

In the long-term, diet, exercise and conservative treatment are not effective enough to manage O-ORD as much as surgery (3-5). As bariatric and metabolic surgery, a lot of techniques have been described from a simple operation like adjustable gastric banding, to more complex procedures like biliopancreatic diversion (BPD). All by-passed techniques, such as Roux-en-Y gastric bypass (RYGB), duodenal switch (DS/BPD), single anastomosis duodeno-ileal bypass (SADI), transit bipartition/its modification and ileal interposition are based on whether the foregut or hindgut theory or the combination of both $(3,6-8)$.

Mini-Gastric Bypass (MGB) has been an increasingly popular bariatric procedure worldwide. A lot of studies have demonstrated the advantages of MGB, and MGB recently has been the third most common bariatric operation in most countries, second common in India (5,9-11). MGB was first described by Rutledge 23 years ago $(7,11,12)$. Although MGB is accepted as a standard technique, still there are 
some doubts about it (4-6). MGB has not been fully recognized worldwide for various reasons such as the risk of bile reflux and unknown cancer in long-term follow-up.

For this reason, researches are ongoing to find the best and most useful technique to treat the O-ORD. Some modifications have been applied to MGB to get better results. One of them is One Anastomosis Gastric Bypass (OAGB) modified by Carbajo in which the created the gastric pouch and afferent jejunal loop are suspended by the continuous sutures both above and below the anastomosis for fixation (13). The other one is obstructive stapleless pouch one anastomosis defined by Ospanov considering a modification of MGB. However, apart from one anastomosis, there are significant differences between Ospanov's technique and MGB (10).

The most important handicap of MGB technique like the RYGB is leaving a closed remnant stomach that cannot be reached by endoscopy in case of complications and emergencies such as bleeding, remnant stomach hematoma, endoscopic retrograde cholangiopancreatography (ERCP) for choledocholithiasis and cholangitis.

In this experimental study, we aimed to modify the previously described technique by leaving a bridge at the most crania part of the fundus to eliminate the handicap of MGB and to solve closed remnant stomach problems.

\section{MATERIAL and METHODS}

The study was approved by the University of Van Yüzüncü Yıl, Regional Committee of Ethics (31008, 03/05/2017). The Experiment was conducted at the experimental animal laboratory of the Veterinary Faculty of the University.

For pre-study, 2 rabbits were given high calorie (Protein: \%17; Metabolic Energy: 2700 kcal; Crude ash: \%7; Crude oil: \%3.17; Crude fiber: \%4.5; Sodium: 0.41 mg/kg; Vit A: 12000 mg/kg; Vit D3: 3600 mg/kg; Vit E: 24 mg/kg) feed for four weeks and weight gain was achieved. 2.1 and $3.2 \mathrm{~kg} 2$ New Zealand rabbits fasted for 2 days before the operation(only free access to water as possible). $5 \mathrm{mg} / \mathrm{kg}$ Xylazine $\mathrm{HCl}$ and $50 \mathrm{mg} / \mathrm{kg}$ Ketamine $\mathrm{HCl}$ were used as anesthesia for the operation.

\section{Surgical Technique}

The operation area of the rabbit was sterilized and a mid-line incision was made from the xiphoid down to the pubis. A shorter incision may be preferred. Scrape fine subcutaneous tissue to expose linea alba. Linea alba was isolated, using a scalpel blade, a blade incision was made parallel to the linea alba (14).

The stomach was explored and prepared for transection. The starting point of the stapler was determined as 2-3 cm away from the pylorus (Figure 1). The lesser sac was reached by cutting the hepatogastric ligament at the incisura angularis, the

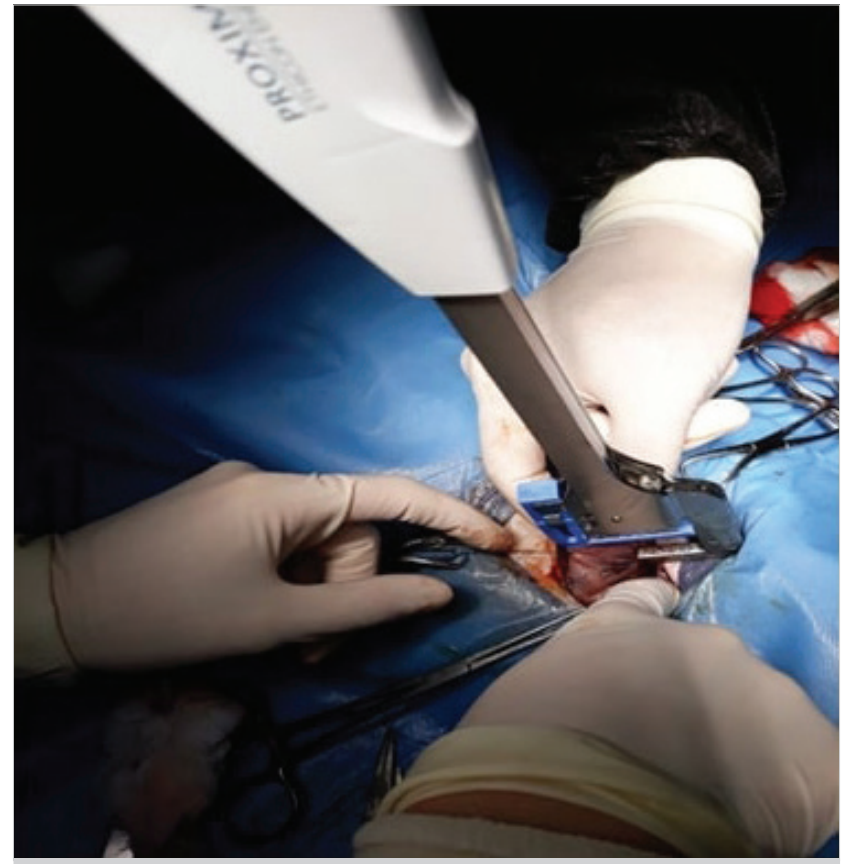

Figure 1. Placement of first stapler and transection of the gastric wall from minor curvature.

stapler (Proximate Reloadable Stapler, 30 mm (TX), 3.5 mm, Blue, Ethicon Endo-Surgery, LLC Guaynabo Puerto-Rico 00969 USA) was pushed forward to the midline $2 \mathrm{~cm}$ in length. After 2 $\mathrm{cm}$, the stapler was directed towards the minor curvature and continued to the angle of HIS. It was terminated approximately $1 \mathrm{~cm}$ before the HIS angle for rabbits. In this way, 30-50\% of the stomach was separated into a chamber. An anastomosis was brought to the stomach chamber by placing the jejunal segment at a distance of about $30 \mathrm{~cm}$ to the Trietz's ligament (could be said two-fifth of the small intestine) (Figure 2). 5/0 polyglactin suture was used for the anastomosis of gastrojejunostomy. After the completion of the anastomosis, the abdominal wall was sutured by $3 / 0$ polyglactin. After the operations, the rabbits were fed post-operatively eighth hour with water.

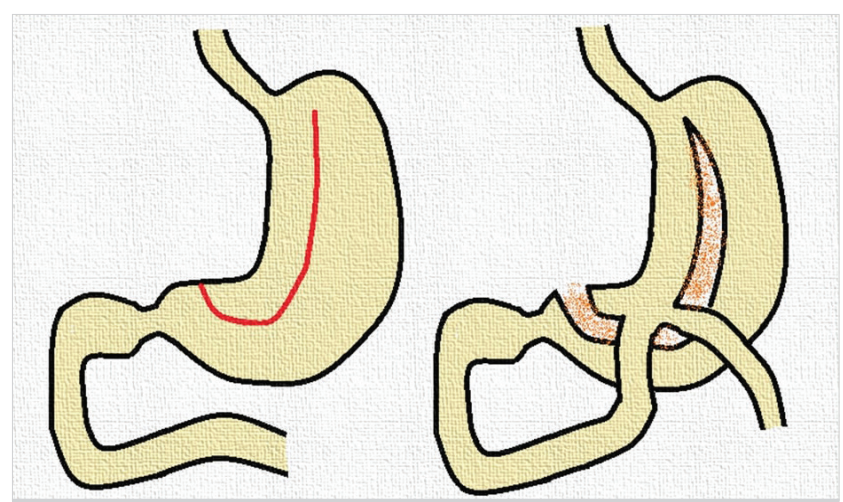

Figure 2. Schematic presentation of gastric resection and formation of gastrojejunostomy. 


\section{RESULTS}

One rabbit died on the same day of the surgery, while the other died after three days. At the end of the third day of the operations, we decided to terminate the study due to the death of both rabbits. During autopsy, any problem with the anastomosis could not be observed. However, necrosis developed at the greater curvature of rabbits.

\section{DISCUSSION}

Philosophically, innocents are not harmed in any religion, holy book, or ideology. However, we, as bariatric surgeons, punish two completely normal organs such as the stomach and small intestine, for the treatment of obesity and diabetes. In this perspective, the most important question to be answered by bariatric surgeons is: How right is it to irreversibly close the remnant stomach or remove a large piece of a completely normal organ to treat other diseases (8).

Bariatric surgery is a very dynamic surgical area. So far, several surgical techniques have evolved to find the best procedure in terms of weight loss and metabolic control that is associated with the fewest side-effects and complications. However, to tell the truth, all defined bariatric and metabolic surgical techniques are historical and go back to Billroth I or Billroth II gastrointestinal anastomosis $(6,8,15,16)$.

MGB is widely used as a third commonly performed primary bariatric procedure after Laparoscopic sleeve gastrectomy (LSG) and RYGB. MGB has been used for about 23 years. This technique was described by Robert Rutledge (12). MGB has some advantages such as a simpler, safer, easier, and faster operation to compare other bypassed techniques. Moreover, evidence shows that MGB has a lower risk of long-term complications and metabolic effects are better than RYGB $(4-6,8)$. On the other hand, MGB has some disadvantages. Mineral, vitamin deficiency, and bile reflux rate are higher in MGB. Recently, some modifications of the original MGB technique have been published by Carbajo as OAGB and by Ospanov as obstructive stapleless pouch one anastomosis $(10,13)$. Nevertheless, these two modifications could not eliminate the most important handicap of the MGB.

The most important handicap of MGB technique, like RYGB, is leaving a closed remnant stomach that cannot be reached by endoscopy $(6,8)$. To eliminate this handicap of MGB and to solve closed remnant stomach problems, we have developed a new modification technique via leaving a bridge at the most cranial part of fundus such as artificial gastro-gastric fistula(GGF). Because the outer diameter of the distal part of the duodenoscope is $13.7 \mathrm{~mm}$, we leave $2 \mathrm{~cm} \mathrm{GGF}(7,8)$.

Possible advantages of this new modified technique can be hypothesized as below:
1. Never touch and destroy the Angle of His

2. Not removing $75-80 \%$ of the stomach as in Sleeve Gastrectomy and protection of organ

3. No short gastric vessel bleeding

4. Allow for endoscopic intervention to observe the remaining stomach (6).

Rabbits are widely used as popular experimental animals and their arterial supply from the left and right gastric arteries, short gastric arteries, and left and right gastroepiploic arteries like in the human stomach $(17,18)$ However, macroscopic descriptions of the arterial pattern often differ and are incomplete in textbooks and atlases as well as in research articles (19).

Ikegami et al. have suggested that short gastric arteries supplied the gastric fundus on the parietal surface of the stomach and the greater curvature which varied in number from 2 to 6 , with 4 arteries (37\%) being the most frequent. (19) In contrast, Abidu-Figueiredo et al. (20) have reported that the number of short gastric arteries varied from 0 to 5, with 0 (33.4\%) being the most frequent and that these arteries, when present, were distributed only to the greater curvature. These differences may be due to the possibility that Abidu-Figueiredo et al. used another breed of New Zealand rabbits, such as New Zealand Red, and/ or were not able to visualize arteries distributed to the parietal surface of the stomach (21). In this current study, two rabbits died at the beginning of the experiment and formed a question in our minds that there may be anatomical variations between rabbit and human stomach. The rabbits may have different fundic arterial supply and the reason for the failure of the technique was attributed to this.

The study of Nath et al. (22) has suggested that there are important differences in the topographical and biometrical anatomy of the digestive tract of rabbits. They have also attributed the reason for these differences to the breed difference. Moreover, they have claimed that the differences in size and weight of the digestive tract of rabbits may also be due to age, food habits, and the effects of the climate. It was determined that gastric arterial supply differed even in their species and also various abnormalities of the digestive tract. The structure and physiology of the rabbit stomach are not suitable for this type of surgery because rabbits'stomach is a natural bezoar. Instead of rabbits; preferring pigs that are more similar to human beings can be considered, especially in gastric operations. (2022). In the current experimental study, two rabbits, on which bridged mini-gastric bypass surgery was performed, were dead because of grater curvature necrosis. This may be the root of the incompleteness of the right gastro-epiploic arterial supply to the fundus. In our another experimental rabbit study, we compared Magenstrasse \& Mill and sleeve gastrectomy, and we lost only two of 20 rabbits. Because of removing greater curvature 
in sleeve gastrectomy, mortality rate was less in this study and was 10\% (23).

\section{CONCLUSION}

As a result, this new technique may be an option for bariatric surgery in humans (at least in theory) but for an experimental model, it is not suitable for rabbits. Rabbits, whose gastric arterial supply differs according to their species, should be reconsidered in terms of gastric surgery techniques, especially in experimental trials.

\section{ACKNOWLEDGMENTS}

The study was supported by Yüzüncü Yıl University Scientific Research Projects.

Ethics Committee Approval: The study was approved by the University of Van Yüzüncü YIl, Regional Committee of Ethics (31008, 03/05/2017).

Peer-review: Externally peer-reviewed.

Author Contributions: Concept - A.Z., T.T.; Design - S.C.., T.S.; Supervision -A.S., T.T., Y.K.; Materials - S.Ç., T.T.; Data Collection and/or Processing - Ç.P., O.A.S.; Analysis and/or Interpretation - T.V.A., Ç.P., T.S.; Literature Search- Ç.P., O.A.S.; Writing Manuscript - T.V.A., T.S.; Critical Reviews - A.S., T.V.A., Y.K.

Conflict of Interest: The authors have no conflicts of interest to declare.

Financial Disclosure: The authors declared that this study has received no financial support.

\section{REFERENCES}

1. World Health Organization 2018. Obesity and overweight. Fact Sheets. (WHO). Available from: https://www.who.int/news-room/factsheets/detail/obesity-and-overweight. [CrossRef]

2. English WJ, De Maria EJ, Brethauer SA. American Society for Metabolic and Bariatric Surgery estimation of metabolic and bariatric procedures performed in the United States in 2016. Surg Obes Relat Dis 2018, 14: 259-63. [CrossRef]

3. Wang FG, Yan WM, Yan M, et al. Outcomes of Mini vs Roux-en-Y gastric bypass: a meta-analysis and T systematic review. Int J Surg 2018; 56: 7-14. [CrossRef]

4. Robert M, Espalieu P, Pelascini E. Efficacy and safety of one anastomosis gastric bypass versus Roux-en-Y gastric bypass for obesity (YOMEGA): a multicentre, randomized, open-label, non- inferiority trial. Lancet 2019; 393(10178): 1299-309. [CrossRef]

5. Parmar CD, Zakeri R, Mahawar K. A Systematic Review of One Anastomosis/Mini Gastric Bypass as a Metabolic Operation for Patients With Body Mass Index $\leq 35 \mathrm{Kg} / \mathrm{M} 2$. Obes Surg Feb 2020; 30(2): 725-35. [CrossRef]
6. Sumer A, Atasoy D, Barbaros U. Bridged mini gastric bypass: a novel metabolic and bariatric operation. Bariatric Surgical Practice And Patient Care 2019; 14: 2: 62-7. [CrossRef]

7. Deitel M, Rutledge R. Mini-gastric bypass: prevention and management of complications in performance and follow-up. Int J Surg Nov 2019; 71: 119-23. [CrossRef]

8. Sumer A, Aktokmakyan TV, Peksen C. Mini gastric by-pass and bridged mini-gastric by-pass: what is new? Ann Laparosc Endosc Surg 2020; 5: 8. [CrossRef]

9. Deitel M. International MGB-OAGB club affiliates with IJS. Int J Surg 2019;61: 76-7. [CrossRef]

10. Ospanov OB. Surgical technique of laparoscopic mini-gastric bypass with obstructive T stapleless pouch creation: A case series. Int I Surg 2019; 67: 70-5. [CrossRef]

11. Rutledge R, Kular K, Manchanda N. The Mini-gastric Bypass original technique. Int J Surg 2019; 61:38-41. [CrossRef]

12. Rutledge R. The mini-gastric bypass experience with the first 1,274 cases. Obes Surg 2001; 11:276-80. [CrossRef]

13. Carbajo M, García-Caballero M, Toledano M. One-anastomosis gastric bypass by laparoscopy: results of the first 209 patients. Obes Surg 2005; 15: 398-404. [CrossRef]

14. Meredith, A, Flecknell, P. BSAVA Manual of Rabbit Medicine and Surgery Second Edition. United Kingdom, 2006; 166-183. [CrossRef]

15. Sumer A. Definition of obesity and current indications for obesity surgery. Laparosc Endosc Surg Sci 2016; 23: 56-62. [CrossRef]

16. Buchwald H. Overview of bariatric surgery. J Am Coll Surg 2002; 194: 367-75. [CrossRef]

17. Barone R, Pavaux C, Blin PC. Atlas d'Anatomie du Lapin (translated into Japanese by Mochizuki K.), Gakusosha, Tokyo, 1973. [CrossRef]

18. Popesko P, Rajtova V, Horak JA. Colour Atlas of Anatomy of Small Laboratory Animals. Volume 1, Saunders, London, 2002. [CrossRef]

19. Ikegami $R$, Tanimoto Y, Kishimoto M. Anatomical variation of arterial supply to the rabbitstomach. Vet Med Sci 2016; (78)4:529-33. [CrossRef]

20. Abidu-Figueiredo M, Xavier-Siva B, Cardinot TM, et al. Celiac artery in New Zealand rabbit: anatomical study of its origin and arrangement for experimental research and surgical practice. Pesqui Vet Bras 2008; 28: 237-40. [CrossRef]

21. Meredith A. General biology and husbandry. In: Rabbit Medicine and Surgery, 2nd ed. British Small Animal Association, Gloucester, 2006; 1-17. [CrossRef]

22. Nath SK. Topographical and biometrical anatomy of the digestive tract of White New Zealand Rabbit. J Adv Vet Anim Res June 2016; 3(2): 145-51. [CrossRef]

23. Sumer A, Celik S, Aktokmakyan TV. Comparison of Magenstrasse and Mill gastroplasty and sleeve gastrectomy techniques as an experimental study on rabbits. Annali Italiani di Chirurgia 2020; 91: 116-21. [CrossRef] 


\section{ORIJINAL ÇALIŞMA-ÖZET}

Turk J Surg 2021; 37 (3): 294-298

\section{Bariatrik cerrahide yeni bir yaklaşım: bridged mini gastrik bypass. Tavşan modeli deneysel bir çalışma için uygun mudur?}

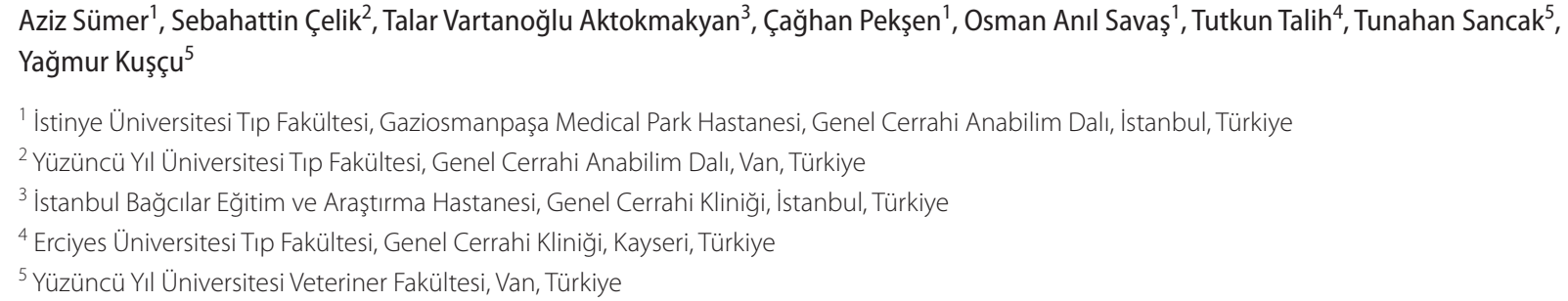

\section{ÖZET}

Giriş ve Amaç: Obezite, önemli morbiditelere neden olabilen küresel bir sağlık sorunudur. Bariatrik cerrahiye artan talep yeni tekniklerin ortaya çıkmasına neden olmuştur. Daha önce tarif edilen Mini Gastrik By-pass (MGB) tekniğini, insan mide fundusunda $2 \mathrm{~cm}$ açıklık bırakarak, kalan mide ve duodenumun takip ve tedavisinde bir köprü olarak kullanmayı amaçladık. Bu yeni tekniğe Bridged MGB adını vererek; deneysel bir çalışma olarak tavşanlara uygulamayı hedefledik.

Gereç ve Yöntem: Bu çalışma, yerel etik kuruldan etik onay alındıktan sonra üniversitenin deney hayvanı laboratuvarında gerçekleştirildi. 2,1 ve 3,2 kg olan iki Yeni Zelanda tavşanı üzerinde tarif edilen yeni teknik uygulanmıştır.

Bulgular: Operasyonlar sonucunda, tavşanlardan biri operasyon günü ex olurken; diğer tavşan postoperatif üçüncü günde ex oldu. Otopsilerde anastomozlarda herhangi bir sorun saptanmamasına rağmen; her iki tavşanın mide büyük kurvaturlarında nekroz saptandı.

Sonuç: Popüler deney hayvanlarından biri olan tavşanın hem arteriyel hem de topografik açılardan insan gastrointestinal sisteminden farklı olduğu ve türlere, hatta diyete ve iklime göre değişiklik gösterdiği vurgulanmıştır. Çalışmamızın bu farklılıklar sonucunda başarısız olduğuna inanıyoruz ve insanlara daha benzer hayvanların gastrointestinal deneysel çalışmalarda kullanılmasını öneriyoruz.

Anahtar Kelimeler: Deneysel çalışma, mini gastrik bypass, tavşan

Doi: $10.47717 /$ turkjsurg.2021.4874 